\title{
The Evolution of U. S. Cultural Diplomacy in the Cold War
}

C ultural exchange across political boundaries is as old as the history of civilization, but the postwar growth of both public and private exchange programs has reached a scale and significance undreamed of a few decades ago. The flow of governmentally supported American scholars going abroad and the traffic of foreign scholars coming to the United States have increased dramatically since the approval of the Fulbright-Hays Act in 1948. This crossing of national frontiers via numerous cultural bridges is very important, not only as an end in itself but also as a major force in governmental relations. The current intellectual and cultural commerce between the United States and other nations has produced radical changes in international relations. Movies, the mass media of communication, tourism, publicity, and advertising have altered the character of national cultures and of international discourse. The activities of universities, foundations, religious groups, fraternal orders, professional societies, and labour unions have contributed to the same end. However, although there exist many opinions about how to conduct the educational and cultural relations of the United States with other countries, few of those opinions are based on a careful attempt to examine fundamental principles.

\footnotetext{
* Middlebury College.
}

In comparison with the abundant and sophisticated studies on the military, the diplomacy, or the commerce of the country with other nations, little systematic attention has been given to educational and cultural policy.

The character of the movement of people and ideas across borders has altered vastly over the last twenty years. The number of people and institutions involved is greater. The social classes and cultural backgrounds from which they are drawn are more varied. The centers of learning to which they go are more numerous, and the places to which they return to use their knowledge are more diversified. Moreover, the framework and objectives of international intellectual and educational relations have changed and grown.

The major portion of the support for such relations still comes from private sources of wealth. The majority of foreign students in the United States today, for example, have financed their stay from their own personal or family resources or those of friends. Nevertheless, to a greater extent than ever before, support for educational and cultural exchange is institutional, and is part of an organized program, conducted by corporations, foundations, universities, religious bodies, and international agencies. And national governments have come to play an increasingly large part in international educational and cultural exchange as regulators of the traffic, censors, 
impresarios, catalytic agents, and sources of support.

Cultural diplomacy is defined as the ample variety of public and private initiatives originating in the United States, and exported abroad with the intention of exerting influence on the cultural and political elites of other countries. The initiative sought to create a friendly appreciation of the United States policies through the reproduction of American values, institutions and beliefs among foreign elites, including exchange programs as well as initiatives to be developed abroad, affecting the areas of education, scientific research, culture at large, professional training, public and private management, labor, military, sports, and political development, among others. Even when many of the programs were not directly managed by the us diplomatic service, I assume that it is safe to say that the us Executive had a fair knowledge of every American initiative going on in a certain country. I would add that even when more than half of the American programs abroad were privately funded by the early 1960s, the majority of them shared the Cold War objectives of the us Government, and relied heavily on public informational or political support. Furthermore, the largest private initiatives in the area of cultural diplomacy, economically speaking, were developed in close coordination with the American State.

This work examines the constitutive stages of the us initiatives in the area of cultural diplomacy, and in particular, the coincidences and conflicts that occurred among the various actors that participated in the project. A brief description of the evolution of the bureaucracy in this area is attached. ${ }^{1}$ The importance of the role of the Ford Foundation is studied through its participation in several instances —origins, design, expansions, operations abroad - of United States cultural diplomacy. The increasing scope of the international operations is illustrated through the analysis of the us policies in the area of International Trade Fairs. The particular case of the Lima International Trade Fair illuminates the us approach to Latin America, which was perceived as a new frontier to be appropriated. In addition, the case study helps understand the relationship between the public and private sectors, and the modes of dealing with the contradictory interests of business, politics and ideology.

\section{The Origins of Educational Exchange and Cultural Diplomacy in the Cold War}

From 1945 on, American cultural initiatives abroad had lost the idealistic approach of their early philanthropic and scientific leadership. Under the tight leadership of an interlocked foreign policy elite coordinated by the Department of State, cultural diplomacy turned into an "organic development" of Us foreign policy. ${ }^{2}$ America needed to close the gap in Latin American credibility in order to counterbalance several factorsunpopular economic policies, support to dictators, domestic racial incidents - that discredited the democratic discourse of its foreign policy during the 1950's. The us needed to demonstrate through new, enhanced programs that "what America says is what America does". ${ }^{3}$

Americans planners aimed at exporting, in fact, more than scientific and artistic paradigms. They promoted the American dream. The export of the complex set of images, symbols, values, technology, science and art was at the same time the export of an ideology in itself. In 
Emily Rosenberg's words, "liberal developmentalism merged liberal tenets with the historical experience of America's own development, elevating the beliefs and experiences of America's unique historical time and circumstance into developmental laws thought to be applicable everywhere". This ideology maintained that "other nations could and should replicate America's own developmental experience". The secular belief in the United States' ability to "perfect and apply laws of progressive betterment and to uplift those lower on the evolutionary scale", was also a religious faith in America's mission. ${ }^{4}$

Throughout this period, cultural diplomacy evolved slowly, exploring different formulas and strategies. In general, the programs complemented traditional foreign policy with the work of new official agencies - Point IV, ICA, USIA, AID- professional organizations - IIE, NSF, SSRC, NAFSA - public and private universities - Harvard University, the California public and private systems, American University, Columbia University - the large philanthropic foundations - the Ford, Rockefeller, Carnegie, and Gillette- and many corporations - most notably, the Hollywood film industry. Although both foreign elites and mass audiences were targeted by the campaigns to "sell Americanism abroad," the policies privileged the idea of influencing the thinking of the cultural and political elites - to gain the world's elites' hearts and minds- who would in turn shape the values and ideas of their specific societies about the United States. All over the world, such diverse programs as Fulbright Student Exchange, USIA Leader Grants, People to People, or English Language Teaching included activities that ranged from the transference of scientific and technical know-how through the sponsoring of paperback editions and Hollywood films to saturation campaigns that advertised TV programs, tourism in the Us, or English as a Second Language.

The Fulbright Act of 1946 and the SmithMundt Act of 1948 were the cornerstones of the initial efforts of United States cultural diplomacy. In addition, the Executive relied heavily on the expertise, management experience, and human resources of many professional agencies from the field of national and international education. For example, the Institute of International Education (IIE) became the major contractor for governmental educational exchange, and the National Association for Foreign Student Advisers (NAFSA), created in 1948, assisted in the management of the visitor's affairs. Some authors believe that there was something similar to a

division of labor among the three major national organizations in educational exchange: the IIE concentrated on administering exchange programs for the government (mostly Fulbright programs and exchanges sponsored by various government departments and agencies) and for private institutions such as the Ford Foundation, universities and corporations; the NAFSA focused on foreign student affairs, especially foreign student advising and immigration issues; and the Committee on Friendly Relations among Foreign Students (CFRFs) concentrated on port-of-entry service and community progra$\mathrm{ms}$ to provide personal help, social/spiritual life and professional experience for the exchange of persons. ${ }^{5}$

MÉXICO YLACUENCADELPACÍFICO vol. 10, núm. 28 / enero-abril de 2007 
Among the most important contributors to the initiative, there was the Ford Foundation, a civilian, non for-profit institution established in the us, without commercial, religious, or political goals, whose resources were entirely destined for educational, scientific, or philanthropic purposes. The entity was absolutely independent from Ford Motor Co. and the Government of the United States. Its resources originated in the profit obtained from commercial and financial assets (among them, the Ford Motor Co.). The Foundation's activities abroad were orientated to creating the human resources that could address the world's economic and social problems through the application of science. The Foundation's strategy in the United States and abroad was designed by mutual agreement between the corresponding entity and Ford. Despite the heavy attack from Conservative forces that did not approve of its educational policies in the United States, the Ford Foundation decided to become part of the diplomatic initiative. The Foundation granted funds to the mentioned IIE, CFRFS, and NAFSA as part of a strategy that coincided with foreign policy objectives of the United States but that stressed the need for peaceful initiatives that multiplied communication channels among the peoples of the world. It could be said that,

the Ford Foundation, the IIE, and the State Department formed a trio that dominated the entire range of exchanges as they respectively exerted exceptional weight in financial resources, service expertise and political leadership. With the IIE acting as the administrative agency for both the State Department and the Ford Foundation, the State Department made clear that "IIE must be willing to accept direction and advice from the State Department' as 'our officers overseas supply information vital to the successfully handling of foreign visitors in the Us". ${ }^{6}$
The emergence of United States cultural diplomacy constituted a process in which multiple forces competed among and against each other in order to participate in the new institutions and to influence the shaping of the emerging policies. The subsequent national Administrations, the various Federal agencies that participated in the policies, the Congress, both major parties, the professional associations involved, many educational and cultural institutions, and the philanthropic sector defended and sought to expand their own area of influence within the emerging political area. In general, it could be stated that the short-term political objectives of the government that responded to the Cold War scenario shaped the policies of cultural diplomacy. In many occasions, the private institutions that participated in the programs did not have a full view of the government's plans and objectives. ${ }^{7}$ The Administrations' political interests were often different from the long-term goals of the other sectors of the American society. Furthermore, the very nature of cultural diplomacy created a serious situation within the government. In fact, in addition to the need of the new institutions to elbow their place through in the discussions on policy objectives, priorities, and funds, their essentially soft strategies were often considered dysfunctional to national security.

A good example of the early debates on the design of the sector was the participation of experienced international educators such as Ben M. Cherrington, who advised against the unification of information and cultural activities. ${ }^{8}$ Such decision seemed to serve the security objectives of strategy planners that were in love with emerging theories on psychological war. However, the mixture of activities of different moral 
hierarchy was repugnant to sectors that perceived international cultural activities on the basis of mutual benefit. Prestigious and experienced institutions such as the American Council of Learned Societies, the American Council on Education, the Association of American Colleges, the National Educational Association, and the Institute of International Education, fully supported the demand for separation. ${ }^{9}$ Despite the fact that the Smith-Mundt Act finally incorporated those suggestions, determining the creation of two separate divisions for information activities and for educational exchange, the former received a substantially superior portion of the budget. ${ }^{10}$

The United States effort in the area of cultural diplomacy depended also on Congressional approval, as much as traditional diplomacy did. It is noteworthy that the traditional isolationist position in international affairs apparently defeated during World War II re-emerged with full force. Many legislators opposed cultural exchange because they were afraid of Communist penetration. Such position meant usual delay in the approval of many programs as well as opposition to the allocation of funds requested by the Executive. Senator Joseph McCarthy did not fail to include the nascent effort of cultural diplomacy in his general attack on President Truman's foreign policy. In addition to his suspicion on the true commitment of Foggy Bottom's patriotism, and even masculinity, Senator McCarthy led an international investigation of the us-supported libraries in Europe in order to determine whether un-American material had been included. ${ }^{11}$

The Smith-Mundt Act also helps describe the dynamics of Congressional politics and the power relations between the political and the educational communities. In addition to the suggestions from the educational sector, the Act bore fierce Conservative opposition that feared the opening of soft flanks through educational exchange, and even enemy infiltration. Only after the Act "carefully and deliberately determined that a program of educational exchange shall become an essential part of the conduct of this Nation's foreign affairs," thus extending the Congressional control on foreign policy to international cultural affairs, was it approved. ${ }^{12}$

Perhaps the most descriptive case of the American decision to mobilize every available resource to fight the Cold War was the initiative of President Eisenhower's closest adviser, to "get Hollywood to understand the propaganda problems of the us and to insert in their scripts and in their action the right ideas with the proper subtlety. This is not a routine problem, but something that has got to be skillfully handled within the context of profitable commercial film production". In addition to the speculative thoughts, the adviser showed a list of the major us film producers that should be called upon for the project. The task would not be difficult, since a group of people had been operating at the studios in representation of Washington, DC. Hollywood's battlefront kept the official busy.

One year earlier, the adviser had been worried about the possibility of having the award for the best foreign picture given to The Small World of Don Camillo, "which in essence says Communism and the rest of the world can get on together." After "a lot of personal work with the various members of the Board of Governors of the Academy of motion Picture Arts and Sciences [...] I think I have them stymied [...] the award will go to "Forbidden Games"'. ${ }^{13}$ The adviser certainly was a resourceful man because, when faced with a similar situation 
-in this case relating to two anti-Catholic films done in Italy by Moravia and Rossellini. "[Even if the] subject matter is of no interest to Us or Anglo-Saxon audiences, it certainly will have some appeal to the Latin Americans, which is precisely a field [...] that has to be watched very carefully. How can we stop this one too? I suppose the Vatican could do something about it". ${ }^{14}$

The decisive intervention of President Eisenhower in favor of cultural diplomacy after 1955 not only strengthened the initiative of the Executive but also helped diffuse the political confrontations on the issue. President Eisenhower took the leadership of the area when he launched the Baylor University Proposals of 1956, which claimed for a major participation of the private sector. In addition, the President encouraged educational and private groups to open new programs that would contemplate the immediate needs of other peoples of the world. Among other initiatives, he created "Foreign Student Day," launched the program People-to-People, and in 1957 supported the Inter-University Committee, which exchanged students with the Soviet Union. Moreover, the government's emphasis on technical assistance and economic aid often combined efforts with international education, as in the case of the training of foreign experts in us universities through the International Cooperation Administration (ICA). ${ }^{15}$

In a word, the us Government supported the expansion of educational exchange throughout the Cold War, relying heavily on the work of professional associations and private groups. The Government's most distinctive asset was to provide leadership for the mobilization of the educational, scientific, cultural, technical, and political resources of the United States in order to direct them to support the national diplomatic efforts. While the us Government's contribution skyrocketed after 1955 , the main expense remained on the part of the professional associations and the private sector. The policy was "even if the government had the necessary resources it would still be desirable that private groups do the bulk of the work in this field". ${ }^{16}$

Latin America was approached from a different point of view by the end of the 1950s. President Eisenhower's creation of the Inter-American Development Bank in 1959 which would soon evolve into the Alliance for Progress - is commonly considered the major turning-point. This initiative reportedly responded to the disastrous outcome of Vice-President Nixon's 1958 goodwill trip. In addition, Brazilian President Juscelino Kubistchek's call for a "Marshall Plan for Latin America," which included warnings of potential social upheaval in the region, influenced the decision. The delicate Cuban process constituted another serious indication of the need for a change. However, while those observations are accurate, it is especially useful to look at earlier signs which point to the United States' attempts to change not only the content of its Latin American policies, but also the tools through which it was developed. ${ }^{17}$

The Administration instructed the USIA, one of its new projects, to address Latin America "expounding the free enterprise system and inter-American economic interdependence; exposing the threat of international communism and its machinations in the area; and demonstrating the positive values of democracy as exemplified in American life and culture". ${ }^{18}$ At its first stages, the new policies were based on a theory of "concentric" structures of information and power-knowledge. That 
approach to information theory stressed the need to operate on the foreign elites' perception of the United States as the best way to reproduce a favorable image among the masses. The documentation clearly indicates that the American officials had a simplistic perception of foreign societies - shaped by a positivistic approach to science- which led them to count on the almost automatic ability of the elites to impose ideas on their societies. Did the officials have a similar perception about the circulation of values, ideas and behaviors in the Us? It is difficult to determine this point here. However, it is clear that many of the exporters of the "American ideology" at the early stages of the campaign shared, absorbed and reproduced Senator McCarthy's positions. Indeed, that was the frame of mind that supported the ban and burning of an extensive list of publications considered to be dangerous for public, democratic circulation and free choice.

Since the "major obstacle facing the realization of NSC's [National Security Council] objectives in Latin America [was] exaggerated nationalism and its concomitant economic statism," it was decided that the "agency's steps to strengthen its cultural program were taken in a special effort to gain the respect of foreign intellectuals (artists, writers, educators, journalists) for American leadership, and to gain their active allegiance to the principles of the Free World". That is, the agency should highlight "those important aspects of the life and culture of the people of the United States which facilitate understanding of the policies and objectives of the Government of the United States". ${ }^{19}$

The treatment of the difficult "Argentinean case" - the so-called appeasement of Perón- were among the most important achievements of the new us policies in La- tin America. Since his 1953 trip to South America, Doctor Milton Eisenhower had been among the stronger voices that clamored for a new - and different- approach to the region. In his path-breaking report on Latin America of that same year, Doctor Eisenhower advocated the need to understand the structural links between the American economies and the United States. The acceptance of his message, and a stronger concern with the stability of the continent were reflected in the 1957 shift to the policy "Trade and Aid," the constitution of the powerful Business Group for Latin America, and the creation of the Central American Common Market. ${ }^{20}$ The expansion of existing educational and exchange programs was also part of Eisenhower's plan to strengthen the inter-American community. Personalities like Eisenhower, Nelson Rockefeller, John Moors Cabot and J. William Fulbright played a decisive role in that shift, sponsoring and developing official and private initiatives, like the USIA's and Rockefeller and Ford Foundations' broad cultural programs. ${ }^{21}$

\section{The Ford Foundation}

By the early 1960's the Ford Foundation had clearly turned into a close ally of the Government's interests abroad. The expertise provided from the foundation was dearly appreciated by the politicians, who resorted to Ford when considering sensitive issues. The "Plan for the Creation of an Annual's President's Honors List" was an initiative that sought to deal with the expansion of the international influence and prestige of the USA document by Ford for the National Security Council reasoned that

[n]one of the great prizes in the Fine Arts is American [...] Even the holding of international scientific meetings is inhibited by various fac-

MÉXICO YLACUENCADEL PACÍFICO

vol. 10, núm. 28 / enero - abril de 2007

25 
tors, including the [security] provisions of the McCarran Act. It is little wonder we are thought to be one of the great underdeveloped regions culturally [...] The world thinks we are a crude, materialistic, and uncultured society. ${ }^{22}$

The Ford official suggested the institution of an important prize, with a large amount of money - around us $\$ 30,000$ - maintaining selection above suspicion of political or other selfish motivation. The strategy was intended to enhance the image of the us through the association with an area that had been traditionally claimed by the Europeans. However, there were several aspects to be seriously taken into account: The us had to "avoid instances - for example, the military - where the granting of honors and distinctions had degenerated into a most pointless scramble by individuals 'with connections"'. The proposed prize had to be awarded, instead, in a ceremony that was visible, objective, with dignity. The advisor warned strongly against the inevitable collusion from the area of national public relations that collaborated with the country's public diplomacy, such as TV and Hollywood. "The important thing is that the ceremony not be degraded into entertainment. If Leonard Bernstein gets an award, he should not be asked in front of the TV to sit down at the piano..." 23

During the 1950s, the Ford Foundation associated with several major American universities under the auspices of the USIA and the Department of State to pursue ambitious, strategic objectives of the Cold War. According to the 1951 Annual Report, the five major areas of activities included peace, democracy, the advancement of economic well-being, education, and knowledge of human behavior. By the end of the decade, the Ford Foundation developed long-term, ten-year grants to several uni- versities to help build non-Western studies into their regular academic programs. The decision meant an additional target to the foundation's previous concentration on experimental studies on development. Including earlier allocations to universities like Chicago, Columbia, Harvard, Indiana, Northwest, Notre Dame, Penn State and Yale, the Ford Foundation gave us\$ $35,865,000$, not including an additional us $\$$ $1,655,000$ for consultants. Here are some examples of funding decisions in the early 1960s: us\$3 million to Michigan University for research on conflict resolution China, Japan, the Middle East; us $\$ 2.5$ million to Princeton for international studies, including Latin America and the URSs; us\$ 2 million to Washington University since 1960 to give support to regional studies on Europe, Africa, Asia, the Near East, and the UssR. Another interesting characteristic of American cultural diplomacy was the allocation of us $\$ 1.3$ million to the Modern Language Association and to the Center for Applied Linguistics to increase the American competence in critical but neglected non-Western languages, and to assist teaching of English in Asia, Africa and the leading languages in international communications. "In both fields, the Center serves as a national clearinghouse for information on personnel, teaching methods, and materials, and as a liaison among government: Agencies, academic centers, and the language teaching profession." ${ }^{24}$

The critical importance that Ford Foundation's funds acquired in cultural diplomacy should not convey the opinion that its relations to the Government were smooth and unproblematic. An exchange between an advisor to President Kennedy and a high official of Ford described below is a good example of the problems that 
were characteristic of their relationship. However, it must be noted that the conflicts detected at this level hardly ever suggested high tension, or the possibility of a crisis that might bring initiatives to an end. At another level, Conservative diplomats had been always reluctant about an overexpansion of cultural diplomacy. In addition, they tended to dislike programs that opened the way for what they perceived as interference from outsiders in diplomatic issues. When the Kennedy Administration made clear its commitment to a massive pump-up of several international progra$\mathrm{ms}$, Conservative voices let their views be heard. In particular, there had been strong critiques about the way that some foundations, handled the administration of their programs. The claim was that the rapid expansion of their operations enabled their Boards to move enormous amounts of money with little or no effective federal control. Perhaps the concentration of such criticism on the Ford Foundation was not unexpected because of both its visibility and the traditional Conservative suspicion of Ford's true ideological agenda.

A report from the National Security Council to Ford Foundation's President addressed the issue frontally. The memorandum criticized Ford's allegedly less than efficient management, although conceding that the Rockefeller Foundation's techniques were far worse, that unexpected over-costs of overseas operations were understandable, and that dealing with faculty at home and abroad was more than complicated. However, the point was made:

The Foundation is over administered is organized by branches and sectors; in each of many areas it has a staff quite large enough for an ordinary foundation, and to an increasing degree these men are themselves framers of policy [... While] some programs had very tight guidelines from the Board, some have been free to make their own rules as they went along [...] the main difficulty is that the Foundation has not been willing to keep its actions few, big, and personal.

As an example of the indicated weaknesses, the report referred to collusive relationships like the one between administrators at Ford and scholars at Harvard University during the 1950's, “both trying to advance their own special purposes within and around regulations laid down from above." In a word, "the Ford Foundation is now in the unusual position that its Board of Directors is a stronger group than its management". ${ }^{25}$

As mentioned above, the argumentation on the management issue did not prevent Ford and the Administration from working together. By the end of the 1950's Latin America was considered an endangered part of the non-Western world that United States cultural diplomacy and the Ford reformers had to operate on. "The next decade will be critical for Latin America's destiny: the result could make it free or slave since we have not yet proven that we can produce growth in underdeveloped societies as we promoted recovery in Western Europe," reasoned a memo to the President of the Ford Foundation. Within the favorable context of the Alliance for Progress and the Peace Corps initiatives, Ford debated how to conciliate its programs, the evolution of its own interests, geographic areas of participation, and its relation with the Government plans. The Foundation acknowledged having granted us\$ 1.3 billion during the 1950s: Among other issues, the main recipient areas had been us $\$ 258.9$ million for international programs; us\$ 259.7 million in hospitals and medical schools; us\$ 71.5 million in economics and business; us\$ 68 million 
in public affairs; and us\$ 533.7 million in education. However, the institution reflected that they "must consider a shift from medicine (except for population control) to areas suggested by the government," with social science, development, and management being the main ones.

The discussion between the Foundation and the National Security Council stressed that the strategy should seek the "training [of] young Latin American technicians, who had the power of political decisions," although an excessively elitist approach was not advised. It was recognized that Ford's actions within the national diplomatic effort " $[\mathrm{n}]$ eed $[\mathrm{s}]$ mechanisms that give us confidence - not two bureaucracies." It was suggested that the Ford Foundation should concentrate in "creating Public Authority in several Latin American nations [...] modeled after the Tennessee Valley Administration, the Public Authority of New York, and the European Authority on Steel and Coal." However, drawing on what by then perceived as a weak flank in domestic politics, it was remarked that the field officials should be overtly careful with respect to a very sensitive issue: the Foundation had to prevent Latin politics from diverting us taxpayers' monies". ${ }^{26}$

As part of the planned movement, the Ford Foundation, in consensus with the us diplomatic leaders, settled in Argentina in 1962. The Foundation became a very important financial source for plenty of Argentinean institutions of different types, including public institutions, private centers and corporations. The Ford Foundation addressed four main issues: industrial, scientific and technological development; Social Science; development of educational systems; and agricultural education and development. A brief description of Ford's allocations between 1962 and 1966 include the us $\$ 25,500$ grant for a four-year period to the Asociación Química Argentina in 1963, for the expansion of its services for the industrial sector. The main activities covered were the development of a library, a journal, and a conference program in industrial and university centers in the Buenos Aires area. Another grant for us $\$ 200,000$ for a four-year period went to the Comisión Nacional de Energía Atómica in 1963. That same year, the Consejo Nacional de Educación Técnica received a grant for us $\$ 242,000$ for an ample program that included a group of visiting faculty from the William Hood Dunwoody Industrial Institute of Minneapolis, and the Brigham Young University. As a result of that mission, two training centers were established in 1963 in Buenos Aires and Córdoba, with the purpose of determining the educational needs of the Argentinean industrial sector. In addition, fellowships to travel to the us were granted with the purpose of constituting the core group that would teach 108 future technical teachers at the aforementioned centers.

In addition, the Fundación Bariloche received us $\$ 440,000$ for the establishment of a Center for Advanced Studies, based on the existing Instituto de Física, at San Carlos de Bariloche. The initiative responded to the demand of a private university from an ample sector. The funds were complemented by another grant from Fundación Fortabat, and by a second grant of Us $\$ 200,000$ in 1966 from Ford, aimed at financing the training of human resources. The Fundación Interamericana de Bibliotecología Franklin received us $\$ 250,000$ in 1964 for the support of a project aimed at the betterment of the book industry in quantity and quality, and its diffusion in Argentina. The Fundación de Investigaciones Económicas Latinoamericanas received us $\$ 380,000$ for studies in 
commerce and economic integration. Ford insisted that the funds should be focused on the study of the integration of Latin America, and the problems of Argentinean productivity. Additional grants went to the Instituto para el Desarrollo de Ejecutivos en la Argentina (US\$288, 500); us\$150,000 for the Instituto Argentino de Racionalización de Materiales (IRAM); Us\$100,000 for the Instituto Superior de Administración Pública; us $\$ 705,000$ in fellowships for the area of Agrarian Economics; a program for summer courses for secondary teachers through the National Science Foundation.

Finally, the Universidad de Buenos Aires (UBA) received various grants of different types from the Ford Foundation. Grants for Us\$210,000 were allocated for teaching and research in the career of Sociology; fifteen professors from the us and Latin America participated in this program, and ten graduate fellowship sent students to the us and England. In addition, UBA received US $\$ 429,000$ to provide the career of Physics with special TV equipment. The Facultad de Ciencias Exactas y Naturales received us $\$ 400,000$ for its labs, us \$53,065 was granted for a visiting profesor of Chemistry, and us\$300,000 in equipment. The Facultad de Ciencias Económicas received us $\$ 275,000$ to support graduate fellowships and visiting professors from the universities of Cambridge and Oxford. Additional grants went to the public universities of Tucumán, Córdoba, Cuyo, and del Sur. ${ }^{27}$

\section{A Joint National Effort: Cultural Diplomacy Forging the us Image in Latin America}

"Sears, Roebuck and Company is not a true representative of the United States of America, and should not be included among the selected group of outstanding companies that represent the American Delegation to the Second International Pacific Trade Fair in Lima, Peru". ${ }^{28}$ In his letter of October 18, 1961 to President John F. Kennedy, John J. Snyder, a representative of an inter-American federation of workers, tried to help solve the crisis that affected the United States' participation in what was perceived as another critical stage of the Cold War confrontation. The crisis had been unleashed almost one year before when the International Federation of Commercial Clerical and Technical Employees rejected the participation of Sears, Roebuck and Co. in the Lima International Fair because of the American company's well-known policies of discouraging union organization. The story of the Lima International Trade Fair helps to illustrate some contradictions in the ambitious program of us cultural diplomacy in the realm of the International Fairs - one of the most original creations of American foreign policy in the twentieth century. ${ }^{29}$ In particular, the "Sears affair" highlights three interesting aspects of the evolution of the perception and planning of the progra$\mathrm{ms}$. To wit, the expansion of the "cultural tools" of Americanism to the International Fairs circuit, the utilization of corporate capital to support the "patriotic" mission, and the focusing on national and foreign labor leadership as desirable instruments and targets of the propaganda policies.

On 1 August 1956, the International Cultural Exchange and Trade Fair Act (Public Law 860, 84 ${ }^{\text {th }}$ Congress) authorized the President to provide for, among other things,

[...] Us participation in international fairs and expositions abroad, including trade and industrial fairs and other public or private demonstrations of United States industrial 
accomplishments and cultural attainments [...] tours in countries abroad by creative and performing artists and athletes from the United States, individually and in groups, representing any field of the arts, sports, or any other form of cultural attainment [...] representation in artistic, dramatic, musical, sports and other cultural festivals, competitions and like exhibitions abroad. ${ }^{30}$

The purpose of the Act was

\begin{abstract}
to strengthen that which unites us with other nations by demonstrating the cultural interests, developments and achievements of the people of the United States, and the contributions being made by the United States economic and social system toward a more peaceful and fruitful life for its own people and other people throughout the world. ${ }^{31}$
\end{abstract}

In the words of the retiring Director of the UsIA, "the Communist Block had exhibits and trade fairs in 41 different countries and in 149 fairs, had 288 exhibits, spending approximately us $\$ 38$ million [...] From the UsSR alone there were 88 cultural and sports delegations to countries of the free world in 1954 [...] against only 37 cultural and seven sports delegations" of the us. The Director challenged the Senate Committee on Foreign Relations: "What are we going to do to meet this grave threat?". ${ }^{32}$

The legislative history of this Act indicates that it was intended to authorize the permanent continuation of ongoing cultural and international fair participation. "From their inception these activities were calculated to counteract similar Soviet bloc activities and more affirmatively to demonstrate in a dramatic and effective manner the quality of our free institutions as reflected in our industrial products and our cultural attainments and to create a favorable climate of opinion in support of Us policies." ${ }^{33}$ The President delegated various functions provided for in the Act to the
Director of the United States Information Agency, to the Department of Commerce and to the Department of State, while the Operation Committee Board (OCB) - through the ocB Trade Fair and Cultural Presentations Committees- would act as the interagency mechanism providing over-all policy guidance and division of funds between trade fairs and cultural presentations. The Chief of Missions abroad would be critical to an effective process of planning, audience-targeting and evaluation of each particular exhibit.

The opportunity for us participation at a certain international trade fair as well as the theme and contents of its exhibits and the evaluation of results would adhere as consistently as possible to certain policy guidelines. It was remarked that "a trade fair exhibit should serve the most important us policy objectives, and the selection of the host countries should be made with this point in mind." In addition, it was desirable to "concentrate more effort at selected points to meet bloc competition effectively [as well as] participate in fairs in neutralist and Iron Curtain countries than in those countries more friendly to the us." While us exhibits should be scheduled no more frequently than every other year, free world countries should be encouraged to participate where the us did not. Other public agencies, such as the Departments of Labor and Agriculture, and private foundations, in particular the Ford Foundation, should be encouraged to enhance the effectiveness of the program.

The document also included similar terms and policies regarding the Cultural Presentations Program, emphasizing the importance of an accurate evaluation of the quality and consistency of the cultural exhibits as well as their convenient adjustment to the unique characteristics 
of the host country. ${ }^{34}$ As an example, when planning an American exhibit in Moscow for the summer of 1959, a White House official confessed that he was obsessed in his search for an

honest and attractive slice of American life [...] that [...] includes a healthy reference to things of the spirit. After all our talk about "godless materialism,"we don't want our exhibit to look like Macy's bargain basement, a kind of starspangled materialism made in the USA. ${ }^{35}$

The International Trade Fair Act constituted a strengthening of the policy line that had been opened two years before, when an ocB Trade Fair Committee was included in the newly created President's Emergency Fund for Participation in International Affairs. The Fund had been originally "appropriated for the basic purpose of promoting various types of projects overseas that will demonstrate in a dramatic and effective manner the excellence of our free institutions as reflected in our products and our cultural values." Chaired by a representative of the Commerce Department, with support from the Department of State and UsIA, the Committee sought to show that the United States was "capable of producing goods and services which it is able to supply through private channels." The document called for private support through "the presence of experienced trade teams to provide information about the us markets" and to expand America's "present prestige and [...] future markets." This strategy would certainly "demonstrate America's productivity and technical progress" and "multiply through a 'seed money' approach the impact of the fair toward us objectives". ${ }^{36}$

Indeed, according to the President's wish that the funds appropriated under the International Trade Fair Act of 1957 be the seed of large private enterprise contributions, "the latter should be sought aggressively." The new policies articulated that the program sought not only to reduce the government's costs but also to "display the system that provides the goods, not the goods alone: Business must be convinced that it will derive rewards not only from direct trade promotion at the fairs, but also in the long run from the climate of opinion created by the fairs". ${ }^{37}$

Two months later, in June of 1957, the Inter-Agency Committee for Cooperation with Private Enterprise (in Overseas Information, Cultural Activities, and Education) was created. Under the chairmanship of the USIA, representatives of virtually all the Departments, including the Central Intelligence Agency, the International Cooperation Administration, the National Science Foundation, and the Ford Foundation, among others, were asked to

assist in the coordination of information and advice, within Government, relating to private efforts to make America more favorably understood abroad [...] and [...] assist in apprising the Office of Private Cooperation, UsIA, of the various overseas programs, both private and governmental, already existent in information, culture and education, so that future private American activity may be encouraged to supplement and complement present efforts in the same general field. ${ }^{38}$

Furthermore, the apparent intent of the designers of United States cultural diplomacy to put more weight on the effort in private hands may be better appreciated if we consider these actions together with President Eisenhower's proposals, made at Baylor University on May 26, 1956. On that occasion, the President "made a plea for greater cooperation between the American people and peoples abroad, announcing 'strong governmental action to assist foun- 
dations, universities, and other private groups desirous of increasing support for educational programs abroad". ${ }^{39}$

Regarding overseas labor affairs, as early as 1955, an Ad Hoc Working Group on Overseas Labor Activity at the OCB was instructed to identify and develop recommendations "with respect to gaps in existing policy in the international labor field." In the case of the relationship between organized labor in the us and official us labor activities abroad, the Committee remarked to the USIA that "to accomplish the said policies requires the initiative and continuing effort of the American and international free trade unions as well as of Government agencies. The unique position, experience and judgment of us trade unionists should be utilized wherever and whenever possible — without compromising the autonomy and independence of free labor - to promote close and effective understanding and cooperation between Government and labor in the field of international labor activity." A valuable example of the coordinated efforts between the Department of Labor and AFL-CIO that effectively reached international labor leaders was the arrangement for more than one hundred leaders from twenty five countries to attend the American Labor Convention held in Miami exactly at the same moment that the Lima Fair took place. On that occasion, "international, top-level and lower-level, freely selected labor leaders - that is, important 'opinion formulators' - were put in contact with the authentic representatives of American workers [...] because the needs and aspirations of workers throughout the world are uppermost in United States foreign policies and programs". ${ }^{40}$

In addition to the decision to implement the position of labor attachés at
American embassies, ${ }^{41}$ "trade relations practices of private us businessmen abroad were also considered a critical component of the export of 'American labor-management relations,' which should be set as an example for foreign employers and workers". ${ }^{42}$ Furthermore, the Department of Labor enthusiastically explained that it engaged selected teams of trade unionists to man labor exhibits that

\begin{abstract}
speak as trade unionists explaining the American philosophy of labor, our system of collective bargaining and all aspects of labor-management cooperation in the Us [...] Considering the fascination that international trade fairs hold for people in all lands [the teams could] communicate with the "grass roots" in foreign countries to explain [...] the aspirations and hopes of American workers. ${ }^{43}$
\end{abstract}

The careful planning of the us delegation to the Lima Fair indicates that the cultural diplomacy of the United States was working at its best: after some adjustments recommended by the President's Committee on Information Activities Abroad of 1960 (also known as the Sprague Committee), the launching of the strong Alliance for Progress in the Americas, and the massive emergence of the private foundations -in particular the larger Ford Foundation programs-American programs were growing in budget, size and scope. New democratic regimes in key countries of the continent identified and pursued the same objective of "modernization" espoused by the State Department, which looked surprisingly similar to the advantageous "American way of life" that us cultural diplomacy actively advertised. Furthermore, the fact that the UsIA decided to send an American delegation to Peru was of no minor importance at a time when the us was reported to attend approximately sixteen fairs yearly that attracted a public of about seventeen 
million persons, and declined more than sixty invitations. ${ }^{44}$

On the other hand, us officials acknowledged that their performance eventually had to confront obstacles of a varied nature. Neither they nor the Peruvian authorities and public nor the leaders of the international union federations forgot that the widespread anti-Americanism of the early 1950's — due to the unfulfilled "revolution of rising expectations"- had not subsided in Latin America. Only three years before, vice-president Nixon had confronted massive anti-Yankee rallies that attacked the very essence of what the American delegation to the Fair tried to promote; and three months before the Fair, in June of 1961, the National University was closed in response to the massive riots organized during the visit of Adlai Stevenson, Kennedy's Special Representative to Latin America. ${ }^{45}$

Other problems could originate in bureaucratic short-circuits. As the Sprague report illustrated,

\begin{abstract}
the most persistent area of disagreement is the result of an innate conflict that has plagued the program since its inception. Though conceived and authorized as a counter-propaganda measure, the program has always had strong commercial overtones. Conflicts between the two purposes have influenced the organizational assignments [...] Habitually the propaganda forces held the upper hand. Today, with the adverse balance of payments picture lurking in the background, the trade promotionists are gaining momentum. ${ }^{46}$
\end{abstract}

In addition, unresolved cultural issues could become a major public relations problem, like when Indian authorities banned the exhibition and advertisement of alcoholic drinks that composed part of the American exhibit in their country's trade fair. ${ }^{47}$
Perceived political or ideological contradictions in the United States could also be used as a weapon against its fairs: at the Soviet Union's Trade Fair held in Stalingrad in 1961, a minor incident in which an American female official declined an invitation to dance made by a dark-skinned Indonesian man who accompanied a Black official of the American delegation was held by the local press as yet another example of the racial discrimination that America tried to disguise. ${ }^{48}$ Furthermore, the organizers of the United States exhibits also had to deal with conflicting interpretations of what constituted the "best," or the "truest" representation of the "real" America. An American visitor to the International Fair of 1958 in Brussels angrily reported to the State Department "how inconveniently and inconsistently the life and values of the United States were misrepresented through an odd combination of 'so-called modern art' and yellow journalism. "The denunciation challenged the innovative initiative of the exhibit organizers who had opened a wing of the American pavilion with the title "USA Today" - highly attended by the public. The exhibit incorporated abstract expressionism as a sample of the evolution in American art, and presented a set of photographs of brutal police repression during the increasingly frequent race riots in the South. In the opinion of the angry denouncer, enemies of the country distorted the characteristics of the Us institutions and traditions by concentrating solely on fashionable, inferior art products and by magnifying exceptional situations of unrest. "Why cannot we be represented by Edward Hopper and images of our common people at work?" he demanded. The contents of the exhibit at Brussels were immediately replaced. ${ }^{49}$ 
The Second International Pacific Trade Fair of 1961 in Lima constituted an important event for American diplomats and businessmen. The American delegation hosted more than one hundred manufacturers that showed not only the power and sophistication of the industry of the United States but also the dynamics of their Peruvian partners. As reported by the manager, Commerce Department's John U. McManus, the 60,000 square feet of the exhibit's four giant buildings were designed to impress the local businessmen by including products as varied as heavy duty capital goods, a complete TV assembly lineAmerican products, Peruvian assemblersan enormous sphere of nylon cloth supported by four tall aluminum struts, a 12,000 square foot structure supported by a single central mast, and two brand-new bowling lanes with automatic pin-spotters..$^{50}$

But how can the case of Sears, Roebuck and Co. in Lima be assessed within the described context? John J. Snyder, the aforementioned inter-American union representative, complained to President Kennedy about the anti-union history of Sears, Roebuck, claiming that its presence "defeats the purpose of the exposition [while] other corporations are more representative of us labor relations". ${ }^{51}$ In addition, his warnings regarding the possibility of a "general boycott to the company urged by Consumers of America" threatened to be only the first step in a longer chain of "highly unfavorable reactions among Latin American unions [that would damage] the long sought development of democratic continental solidarity". ${ }^{22}$ In a long response to Mr. Ernest S. Lee, the inter-American Representative of the International Federation of Commercial, Clerical and Technical Employees, Frederick C. Dutton, Special Assistant to President Kennedy, remarked that "the matter had been of deep concern to the Administration for a number of months."

By October of 1961, "several departments of the Government have been actively involved in appraising the situation and in attempting to facilitate an accommodation of views between the Retail Clerks International Association and the Company" but only with "partial success," as reported to the president of the union, Mr. James Suffridge. Mr. Dutton, the Us Official, explained that

\footnotetext{
almost one year prior to the beginning of the present Administration, Sears, Roebuck was given an opportunity by the United States Government to contribute its experience and know-how to the Lima Fair [...] on the important ground that this Company had achieved a relationship with Peruvian companies that demonstrated the Kind of local cooperation between American and local enterprise that we consider constructive. ${ }^{53}$
}

In fact, Dutton relied on the fact that Sears, Roebuck \& Co. -considered a valuable representative of American culture - had collaborated with the Us Government's operations abroad for a long time before this incident took place. USIA valued the strong symbolism of Sears, Roebuck \& Co. and used to send out gifts from Sears, Roebuck's and Montgomery Ward's mail order catalogs. Having been a "familiar merchandise compendium in millions of American homes for generations [these catalogs] are playing their part in promoting better understanding of American life abroad, and are fertile sources of craftsmanship ideas in foreign lands". ${ }^{54}$ Additionally, the Special Assistant to the President insisted that it was only "months after this invitation was extended and that much work was done by the Company and by the United States Government that 
recommendations were made to this Administration to cancel the invitation."

Since the Sears exhibit would feature not only that company's operations but also exhibit the many Peruvian products that it distributed, Dutton stressed that "it would be highly disruptive to the arrangements for the Fair, and a breach of previous commitments, to accede to the union's request at this time," not to mention the possible damage to the image of the whole national delegation. ${ }^{55}$ Basically, Dutton's message stated that the organizers did not plan to intervene in the Sears affair, which meant that the company would represent the us at Lima albeit not handling its labor affairs in the advertised "American way." The Special Assistant's letter to the interAmerican Labor representative conceded that under the ethics of the American way "the right of all groups to speak out must always be protected." However, he then switched from a defensive position to a discourse that described the ideological basis and the political limitations of the United States diplomatic effort: In the first place, his opinion was that the most immediate concern of the whole incident was in the danger of Communist infiltration and exploitation of the incident.

\begin{abstract}
The danger is that activities directed against a single company, no matter how worthy you consider those activities, can easily be interpreted as considered against all of the companies involved--including many with excellent labor records here in the United States and actually as activities against the American Government generally and its basic labor policies.
\end{abstract}

In addition, he remarked, "it has not seemed appropriate [...] to make a decision on the Fair on the basis of the dispute going on in this country between a union and a company." His final words stressed the need for a lengthy discussion of the affair, but not without a warning: Lee, the Special Assistant reasoned, was "in a key position to put this problem in its proper perspective. As an American citizen, you would not knowingly embarrass or hurt your country at this very crucial time in our history". ${ }^{56}$

What does the Sears affair tell us about cultural diplomacy? A general consideration allows us to say that the American exhibit in Lima was successful. The Peruvian political climate - traditionally not favorable to the us- was marked by the dramatic realignment of the American Republics with the United States after the Bay of Pigs incident. However, despite strong political and diplomatic efforts, the image of the us remained vulnerable. But it has to be recognized that some criticism of the "American way of life" was expected. Furthermore, us Officials had discounted that Latin American labor would focus on Sears - as it obviously did - to stress the different understanding of labor relations throughout the Americas. In fact, the Latin Americans criticized the existence in the Us of three labor organizations of different ideological and political background, which competed for the representation of the continental workers.

However, the decision of the administration deserves further analysis. In order to fight the battle against Communism, Us cultural diplomacy promoted multiple sectors that voiced diverse, constructive images of the American civilization. While it is true that business strategically supported cultural diplomacy, it is also important to remember that the Administration supported, directly or through AFL-Cio leaders, a vast network of American and non-American labor leaders throughout the Americas and the world. Notwithstanding the openness and display of strong confidence 
in the innate superiority of the American institutions, fear of exploitation of domestic problems by the enemy quickly led the Administration to reward corporate interests. Since the correspondence infers that national and international organizationsand pro-communist organizations-would press the Sears issue before us Diplomats in any case, it may be concluded that the importance of the different sectors in the diplomatic strategy put labor interests in a second place.

In addition, it is very interesting to note that the discourse of Americanism and anti-Communism that was conveyed abroad through cultural diplomacy was implemented at home through more traditional, albeit constraining references to non-confrontational labor relations, tougher labor laws and patriotism. Notwithstanding the labor leader's duties as a worker and inter-American representative, it was ultimately stressed that it was his obligation to respond to the interests of the us as defined by the Special Assistant at the moment-that is, as an American citizen, he had to silence the problem and compromise over the Sears issue.

Undoubtedly, promoting the institutions of the United States abroad with credibility was not a simple task. Not only did the group of us officials and citizens have to overcome the challenge of comprehending foreign cultural codes but also - and most importantly - they had to agree on the best and truest combination of elements that expressed the legitimacy and vitality of American institutions. Yet, ultimately, they were unable to prevent the inherent contradictions of American life from surfacing in the exported images. While us cultural diplomacy conveyed a new symbolic identity-international, classless, raceless -that would create a friendly American public around the world-, it is clear that those images were highly vulnerable to incidents that involved domestic American issues like us citizenship, business leverage on governmental decisions, or repression of ethnic groups. In the same skeptical way that African nations received the Black sportsmen and artists recruited by the USIA, Latin American labor organizations just refused to "buy a recipe" of labor relations that was partly resisted in the us and did not reproduce the conditions in Latin America.

A recent article on the Us domestic information campaign notes that the officials in charge of designing, developing and monitoring us cultural diplomacy did so by recruiting private groups who did the covert propaganda work for the national security state. Several officials and businessmen reflected on the fact that often they would have to face the apparent contradiction of their mission with democratic principles and run the risk of being referred to as "propagandists." In the words of the article's author:

That puzzle lies at the heart of Cold War consensus. Even when studying its most self-conscious designers, separating deliberate manipulation from avowed belief from embedded culture proves tricky. This seamlessness might suggest authentic belief, but the very formulation of democratic truth and totalitarian distortion that seemed so fervently felt became the very rationale government information officers used to abandon candor as their guiding policy. In their war for hearts and minds, they embellished the truth in order to save it, but they seem to have forgotten they did so. ${ }^{57}$

\section{Toward Latin America and Argentina}

Throughout the 1950's, the us developed an unprecedented set of policies in the area of cultural diplomacy. Increasingly, since the first moves by Senator Fulbright 
in the mid 1940's through the creation of agencies like the USIA in 1953 to the incorporation of the major American business, educational institutions and philanthropic foundations, us cultural diplomacy ended up mobilizing an amazing number and variety of resources. In addition, the initiative designed increasingly varied activities that included educational, library, language, commercial, technical, labor, military, sporting, philanthropic, and religious programs, among others. As explained above, the formation of the new institutions, the needed human resources, and the doctrine of cultural diplomacy followed traditional American lines. Hence the process of fertile exchange - tense or otherwise - among initiatives of the public sector, the most traditional cultural and educational institutions, business and the philanthropists within the context of Cold War partisan confrontation.

The active leadership of the United States Information Agency after 1953 confirmed the us's increasing commitment in Latin America. The deploying of resources in the area of international trade fairs -involving resources from the business, labor, political, and public relations sectors - was a clear example of the increased scope of the programs aimed at the "Latin American frontier." In addition, the incorporation of the resources of the Ford Foundation to the initiative coincided with the stronger leadership imposed by the Presidency in the second part of the 1950 's. The Foundation was ubiquitous to provide its resources, structure, expertise, flexibility and domestic connections to the us interest in the "non-Western world," which included Latin America.

The collaboration of Hollywood with United States cultural diplomacy toward Latin America - and toward the rest of the world, too- should serve as graphic evidence of the said variety and dynamics of the initiatives, as well as to observe the type of conflicts that occasionally arose in the cultural programs. In 1956, the Director of the UsIA, Sigmund Larson, stressed the value of media resources in a letter to the President: "The impression of America abroad can be affected only to a degree by the USIA. Major influence in depicting our people and our way of life in other countries are the American motion pictures, paperback books, and films for TV which are exported." Larson also pointed at a contradictory effect of such strategic resource: "These have ready acceptance abroad and make handsome profits for those who distribute them [However] in a large measure they [attract criticism form our enemies because they] play up sex and crime." Referring to a recent meeting between President Eisenhower and influential American businessmen of the motion picture, publishing and TV industries, the Director of the USIA concluded that "the group of citizens you have called to Washington, DC, could perform an invaluable service if they could set up voluntary controls on the export of books, motion pictures and TV films which give such a false and misleading impression of what we are and how we live". ${ }^{58}$ Interestingly, Larmon's suggested solution was representative of the corporatist strategy implemented by United States cultural diplomacy that aimed at involving increasingly more sectors of the economic elite with the state-led initiatives. The UsIA expected the economic leaders' self-censorship in order to mold the content of their product to a desired profile.

As mentioned earlier, Milton Eisenhower was one of the first and main advocats of the idea that it was urgent to 
redesign the master us policies toward Latin America. Through the lengthy report to the President examined above, Doctor Eisenhower pressed his point with the Executive, at the level of the National Security Council, and through scrupulous discussion at the influential Business Advisory Committee on Latin America. By October 1954, Doctor Eisenhower threw all his weight on the issue of the leadership of the us delegation to the Inter-American Economic Conference in Río de Janeiro, explaining to the President that he would not be part of the delegation if George Humphrey was chosen to be the leader. Doctor Eisenhower was"persuaded that George is not friendly to a cooperative effort toward Latin American development, and I do not believe he will be a good soldier and carry out orders in the spirit of an agreed-upon program." Against the fragile consensus on more cooperative policies toward Latin America that the Eisenhower brothers and Dulles had carefully knitted together despite a hostile environment, Humphrey had vented his opposition to a more liberal role for the Export-Import Bank, which was "the real key to the execution of American policy with Latin American nations." Doctor Eisenhower protested that "there continues to be evidence that some of the top officials of our government consider friendly relations with other parts of the world to be more important to us than similar relations in the hemisphere." Hence the inevitable conclusion and discouragement of the Latin Americans with the faster and larger provision of assistance, they have more urgent problems than to friendlier nations. ${ }^{59}$

Later that year, Latin America's place in the priority list of the us strategic interests continued to be at the center of the political debate. Some of the decisions that had to be made, created difficult situations for the policy-makers. By December 1954, President Eisenhower responded to his brother's insistence on the need to pay attention to Latin America. The President reasoned that "we should not forget, however, that countries like Burma, Thailand, and the remaining parts of Indo-China are directly open to assault. This does not apply in South America. Sometimes I feel like paraphrasing an old saying and making it read, "The way of the giver is hard."

However, the President accepted Milton's views at the level of long-range policies. The President concluded that while in Asia "we are primarily concerned with meeting a crisis, establishing firm and friendly friends and making certain that... [those countries] do not fall into Communist hands," the Americas were different. Writing shortly after the French forces' unexpected 1954 disaster in Vietnam, although still unable to imagine a future Socialist Cuba, the President stated that "in the case of South America, we want to establish a healthy relationship that will be characterized by mutual cooperation and which will permanently endure. This will apply whether or not the Communist menace seems to increase or decrease in intensity". ${ }^{60}$

By the end of the decade, reflecting the set of new recommendations on public affairs by President Eisenhower, the Assistant Secretary for Inter-American Affairs discussed with the Ambassador to Argentina some possible steps for the near future. The officials confirmed previous conclusions that the us action in Latin America should be developed urgently, taking advantage of the favorable attention of the Administration. The situation in the continent was perceived as increa- 
singly ominous. Hostile responses to the United States tended to become the rule in the continent, both from the elites and popular sectors, as was learned bitterly through Vice-President Richard Nixon's widely protested trip to the region in 1958. The Ambassador stated that the actions to come should be developed not only in the Latin American countries but also in the United States. The President's urge to have "the American public informed about inter-American affairs" was thought to be "indispensable [...] so as to increase understanding among the people of this country generally". ${ }^{61}$ Such resolution should confirm that the us political leaders had a strong sense of urgency within the frame of the Cold War, as well as strong confidence in the power of the new strategic resource.

However, by 1958 the observations of the Ambassador to Argentina on the ongoing limitations in "an area where some further action might be taken [...] that of private foundations and American business interests," indicated that there still was a distance between the Administration's decisions and the implementation of such policies at the country level. The coordination of American cultural diplomacy still needed to be improved, the diplomat complained, because "so far [...] I am able to discover that the [State] Department has only a formal contact with the foundations. While the foundations and business interests understandably have no wish to be dictated to or pushed by the Government and may hence be very sensitive about any approaches by us, there is surely some room for legitimate urging by us regarding scholarships and similar items." Reasoning that "it could be mutually advantageous to coordinate exchange activities [with the foundations] and business to maximi- ze benefits rather than to duplicate," he strongly recommended to establish strong liaisons with them. The near future would see the Ambassador's interest come true in Argentina. กำ

\section{Notas}

1. The Organization of Overseas Information Functions: A History of the Organization Pamphlet, "The Organization of Overseas Information Functions," Folder USIA-OIP, 1955, Box CFR Subjects Ind., Reference Service, The Library of Congress. Herbert Hoover Presidential Library.

2. An excellent work on the origin of this initiative is Frank Ninkovich, The Diplomacy of Ideas (Cambridge, 1981). For additional reference, see Mark T. Berger, Under Northern Eyes: Latin American Studies and Us Hegemony in the Americas, 1898-1990 (Bloomington, 1995); Fitzhugh Green, American Propaganda Abroad (New York, 1988); Emily Rosenberg, Spreading the American Dream (New York, 1981); José Manuel Espinosa, Inter-American Beginnings of $U$ s Cultural Diplomacy (Washington, DC, 1976); Kenneth L. Kornher, The Psychological Instrument of U.S. Foreign Policy: USIA,_19531963 (Ann Arbor, 1970); Charles Frankel, The Neglected Aspect of Foreign Affairs (Washington, DC, 1965); Charles Thomson and Walter H. Leaves, Cultural Relations and us Foreign Policy (Bloomington, 1963).

3. Program and Media Studies (PMs) 30-58-7. "The Credibility of What America Says Abroad," Box 1 1965-58 \#1-35, Program and Media Studies Series, United States Information Agency Records, Record Group 306, National Achives and Records Administration.(hereafter RG 306)

4. Rosenberg, Spreading, 7.

5. Liping Bu, "Foreign Students and the Emergence of Modern International Education in the United States, 1910-1970.” (Ph.D. diss., Carnegie Mellon University, 1995), ch. 6.

6. William C. Johnstone to Chester Davis, memo., 27 February 1951, PA 51-29, Ford Foundation Archives. Quoted in Liping Bu, "Foreign Students," chapter 6.

7. The ideological war between the United States and international Communism intensified after the Korean War. A "Campaign of Truth" was initiated calling for a "worldwide Marshal Plan in the field of ideas." 
8. Cherrington was the Director of the Social Foundation Institute at the University of Denver and had served as the first chief of the Division of Cultural Relations of the State Department in 1938-1940 when the government embarked on educational exchange with Latin America.

9. Ben M. Cherrington, "Ten Years After," Association of American Colleges Bulletin, 34 (December, 1948): 507-509, 520.

10. Liping Bu, "Foreign Students," ch. 6.

11. Time-Herald, Washington, Dc, 30 October 1953. Fulbright Papers, second accession, Dos, series 2, Educational and Cultural Exchange, Box 14b, Special Collections, University or Arkansas Libraries.

12. First Semi-annual Report of us Advisory Commission on Educational Exchange (February 1949), p.4.

13. c.D. Jackson to Governor Sherman Adams, The White House, 1-19-54, Box c.D. Jackson Records, Folder 1, DDEPL: OSA-NSA.

14. C.D. Jackson to Owen [no last name available], 1-24-53, Box c.D. Jackson Records, Folder 5 Movies, DDEPL: OSA-NSA.

15. "Third Report of the ICA Inter-Agency Working Group on University Relationships, April 14, 1960."NAFSA Association files, box 14, NAFSA Archives. Melvin Fox, "Why Foreign Students: Need for New Look at Educational Exchange", September 15, 1961, p. 7. Ford Foundation Archives, Report \#003166.

16. The us Advisory Commission on Educational Exchange, "Report to Congress," December 9, 1949. (See Johnson and Colligan, 1965, pp. 3436.).

17. Milton Eisenhower, "United States-Latin America Relations: Report to the President," Department of State Bulletin 28 (Jan.-Jun. 1953), 695-717. A strong defense of the Eisenhower Administration's "earlier" shift in its Latin American economic policy is in Ronald Cox, "Foreign Policy, Private Interests, and the Origins of the Central American Common Market." Paper given at SHAFr Annual Meeting, Waltham, MA, June 1994 (and his forthcoming book).

18. Milton Eisenhower, "Address Before the Dallas Council On World Affairs," Dallas, 3 March 1955. Folder (F.) Latin America 2 and 4: Milton Eisenhower, Geographical File 1954-59, Office of Documentation on Congressional Relations, Box 5, Record Group 469 (USIA), National Archives and Records Administration (NARA), Washington, DC (hereafter RG followed by the record group number and a decimal number). Here he mentions the increasing educational exchange program, the number of governmentsponsored visits of American scientists, as well as the Bi-national Centers, as the tools for "creating a better understanding of the economic interdependence of the Western Hemisphere." Peter Bales, "Nelson Rockefeller and the Quest for Inter-American Unity," Ph. D. Dissertation, SunY at Stony Brook, 1991 also highlights the importance of Milton Eisenhower's leadership in the subject.

19. General Recommendations for the United States Foreign Information Program, us Department of State, Papers Relating to the Foreign Relations of the United States, 1955-57 (Washington, DC, 1989) 9: 504-614. By 1954 the program was already working hard in Latin America, and had developed major activities at several countries as well as at regional conferences. Yet, at its early stages the Agency was worried with getting the necessary funds and with the permanent struggle against Senator McCarthy's attacks. Depiction of the United States as a peaceful and non-colonialist power was of the greatest importance, as well as its ability to have developed an equalitarian "People's Capitalism."

20. Folder President's Baylor University Proposals, осв Series, Box 1, White House Office, National Security Council Staff: Dwight D. Eisenhower Papers as President, 1948-61. Dwight D. Eisenhower Presidential Library, Abilene, Kansas

21. Testimony before the House Foreign Affairs Committee in October 1945. H.R. 4368. The second statement is in Us Department of State Bulletin 13:589-93 (July-December, 1945). Before World War II, the United States government basically left international cultural and educational activity to private efforts. Private institutions such as the Rockefeller philanthropies and religious organizations emphasized goodwill and world peace as their goal of educational exchange. The us government began to sponsor limited cultural activities with Latin America (as part of President Roosevelt's "Good Neighbor Policy") to counteract European cultural expansion in western Hemisphere in the 1930s. The exchange programs with Latin America eventually became a prelude to the government's total involvement in worldwide exchanges in post-1945 years. For information on Inter-American cultural activities, see J. Manuel Espinosa, The Inter-American Beginnings of Us Cultural Diplomacy, 1936-1948 (Washington, Dc: State Department, Bureau of Educational and Cultural Affairs, History Studies, Us Government Printing Office, 1976); Francis J. Colligan, "Twenty Years After: Two 
Decades of Government Sponsored Cultural Relations," The us Department of State Bulletin 39 (1958): 112-120.

22. Letter, Waldemar Nielsen to Walt W. Rostow, Special Advisor to the President, 2-28-61, Folder Ford Foundation 3-18-61/ 3-26-61, Box 297, Subject Series, National Security Files, Archives of the John F. Kennedy Presidential Library.

23. Letter, Waldemar Nielsen to Walt W. Rostow, Special Advisor to the President, 2-28-61, Folder Ford Foundation 3-18-61/ 3-26-61, Box 297, Subject Series, National Security Files, Archives of the John F. Kennedy Presidential Library.

24. News from FF 10-20-61: Grants, Folder Ford Foundation 1959, Archives of CONICET.

25. Memorandum for the Honorable John McCloy, from MacGeorge Bundy, 4-4-62, Box 297, Subject Series, National Security Files, Archives of the John F. Kennedy Presidential Library.

26. Memo to the President, 3-18-61, Folder Ford Foundation 3-27-61/ 4-3-62, Box 297, Subject Series, National Security Files, Archives of the John F. Kennedy Presidential Library.

27. "La Fundación Ford en Argentina," Folder Ford Foundation 1959, Archives of CONICET.

28. Letter, John J. Snyder, Assistant Inter-American Representative of the Postal, Telegraph and Telephone Workers, to President John F. Kennedy, 10-18-61.John F. Kennedy Presidential Library (JFKPL), White House Central Files (WHCF), Box 242, Folder (F) Fo 3-3-4/co).

29. "General Recommendations for the United States Foreign Information Program," United States Department of State, Papers Relating to the Foreign Relations of the United States, 1955-57, Washington, DC, 1989, n. IX, 504-5.

30. Memo "General Policy and Operating Guidance for the President's Special International Program", Operations Coordinating Board, 4-26-57. Confidential. Dwight D. Eisenhower Presidential Library (DDEPL), White House Office: National Security Staff Papers, 1948-1961 (wHo: NSCSP), Operations Coordinating Board: Central Files Series-16, осв 007. Cultural Activities, File \# 3 (2) (2-6-57).

31. Cf. "General Policy and Operating...," DDEPL, WHO: NSCSP.

32. Letter, Rep. (NJ) Frank Thompson, Jr. To President Dwight D. Eisenhower, 11-14-56. DDEPL, Central Files Series (CFS), Box 12, Office Files 110-F, Folder 543.

33. Cf. "General Policy and Operating...," DDEPL, WHO: NSCSP.
34. Cf. "General Policy and Operating...," DDEPL, WHO: NSCSP.

35. Memo "Moscow Exhibit" from Frederic Fox, The White House, to Karl Barr, 2-25-59. DDEPL, Office of the Special Assistant to the National Security Agency (OSA-NSA), OCB Series, Subject Subseries, Box 2 Folder Exhibits, Fairs, etc (2).

36. Memo "General Policy and Operating Guidance for the President's Emergency Fund for Participation in international Affairs-Fiscal Year 1956," осв, Confidential, 6-29-1955. DDEPL, wHO: NSCSP, Operations Coordinating Board: Central Files Series-15, осв 007. Cultural Activities (1), (6-11-55).

37. Cf. "General Policy and Operating...," DDEPL, WHO: NSCSP.

38. Memo "Terms of reference for OCB Committee on Cooperation with Private Enterprise in Overseas Information, Cultural Activities, and Education”, OCB 6-12-57. DDEPL, WHO: NSCSP, Operations Coordinating Board: Central Files Series-16, осв 007. Cultural Activities, File \# 5 (5) $(2-6-57)$.

39. Memo "Follow-Up on President's Baylor University Speech," осB, confidential, 8-24-56. DDEPL, wHo: NSCSP, o: Central Files Series-108, осв 350 \# 4 (3).

40. Memo "Winning Foreign Worker Support for U.S. Foreign Policy," The Secretary of Labor to President John F. Kennedy, 10-26-61. JFKPL, wHCF, Foreign Affairs, Box 248, Folder 6-2 Scientific, Cultural and Exchange Activities 11-28-60 / 11-30-61.

41. Report "Conclusions and Recommendations of the President's Committee on Information Activities Abroad," Sprague Committee, Secret, December 1960. DDEPL, Us President's Committee on Information Activities Abroad (Sprague Committee) Records, 1959-61. Accession 83-10, Series IV PCIIA Report Series, Box 26.

42. Memo., "Recommendations with Respect to the Gaps in International Labor Policy," OсB, Confidential, 5-16-55. DDEPL, wHO: NSCSP, Operations Coordination Board: central Files Series-13, осв 004.6 (Overseas Labor Activity), File \# 1 (2) $(12-54 / 6-55)$.

43. Report "International, Cultural, and Educational and Exchange of persons, Programs and Activities of the Department of labor," Department of labor, 1959. University of Arkansas Libraries (Fayetteville, Arkansas) (UAL), Special Collections Division (SCD), State Department (SD), Cultural Affairs Division (cu), Container 31, Box 5, File Jose Manuel Espinosa, 1958-59. 
44. "Report on the Trade Fairs Program," ocB, 10-560. DDEPL, OSA-NSA, осB Series, Subject Subseries, Box 2, Folder Exhibits, Fairs, etc. (2).

45. "Demonstrations during Stevenson's Visit to Peru," The New York Times, June 18, p.4:5.

46. "Report On the Effectiveness of the us Trade Fair Program in furthering us Foreign Policy Interest," Sprague Committee Report \# 32, Secret, December 1960. DDEPL, Sprague Committee Records, 1959-61. Accession 83-10, Series IV PCIIA Report Series, Box 26.

47. "India Bans Alcoholic Beverages," The New York Times, 9-5-61, p.32:1.

48. "A Racial Incident in the Us Exhibit at Stalingrad," The New York Times, 11-16-61, p.4:7.

49. Personal communications. Pablo Pozzi, 5-25-97. The reference was probably made with reference to Memo "Cultural Presentations for FY 1963," from ocer. Gordon Anderson to cu Alfred V. Boerner, 12-18-61. UAL, SCD, SD, CU, Container 26, Box 7, Folder Cultural Presentations 1959.

50. "Us Exhibits Abroad," The New York Times, 7-2-61, III, P. 5:4.

51. Letter, John J. Snyder to President Kennedy.

52. Letter, Daniel Benedict, Inter-American Secretary for the International Metal Workers Federations, Intermetal, Mexico, to President John J. Kennedy, 10-18-61. JFKPL, WHCF, Foreign Affairs Series, Box 242, Folder Fo 3-3-4/co.

53. Letter, Frederick G. Dutton, Special Assistant to President Kennedy, to Mr. Ernest S. Lee, Inter-American Representative of the International Federation of Commercial, Clerical and Technical Employees, The White House,
10-18-61. JFKPL, WHCF, Foreign Affairs Series, Box 242, Folder

54. Press release, Theodore Streibert, Director, UsIA, Release \# 9, 10-13-53. Herbert Hoover Presidential Library, West Branch, Iowa (HHPL), Bourke B. Hickenlooper Papers, Foreign Relations Committee: Subjects and Individuals, Box 114, Folder Usia 1953.

55. Letter, Frederick G. Dutton to Ernest S. Lee. 10-18-61.

56. Letter, Frederick G. Dutton to Ernest S. Lee. 10-18-61.

57. Nancy Bernhard, "Clearer than Truth: Public Affairs Television and the State Department's Domestic Information Campaigns, 1947-1952," Diplomatic History 21, 4 (Fall 1997): 566-7.

58. Letter, Sigmund Larmon, Director, UsiA, to President Eisenhower, 6 June 1956, Reference to 13 th. Report of the Us Advisory Commission on Information, Dwight D. Eisenhower Personal Papers, Ann Withman Files, Name Series, Box 20, Folder Larmon (1), DDEPL.

59. Letter, Milton Eisenhower to President Eisenhower, 22 October 1954, Dwight D. Eisenhower Papers, Ann Withman Files, International Series, Box 2, Folder Milton 1954 (1), DDEPL.

60. Letter, President Eisenhower to Milton Eisenhower, 1 December 1954, Personal and Confidential, Dwight D. Eisenhower Papers, Ann Withman Files, Dwight D. Eisenhower Documentary Series, Box 8, Folder DDE 0 12-54 (0). DDEPL.

61. Letter Williard Beaulac, Ambassador to Argentina, to Roy Rubottom, Assistant Secretary for Inter-American Affairs, 3-25-59, Folder Ed. Exchange/ Frondizi, RG 306. 